\title{
Properties of Ligand-Gated Potassium Channels in Neurons of Rat Dorsolateral Septal Nucleus
}

\author{
MASASHI GOTO, HIROSHI HASUO AND TAKASHI AKASU \\ Department of Physiology, Kurume University School of Medicine, \\ Kurume 830, Japan
}

Received for publication March 14, 1997

\begin{abstract}
Summary: Properties of ligand-gated $\mathrm{K}^{+}$channels were examined in neurons of rat dorsolateral septal nucleus (DLSN). Application of muscarine (30 $\mu \mathrm{M})$, 5-hydroxytryptamine (5-HT, $10 \mu \mathrm{M})$, adenosine $(100 \mu \mathrm{M})$, baclofen $(10 \mu \mathrm{M})$ and norepinephrine (NE, $10 \mu \mathrm{M})$ to DLSN neurons caused hyperpolarizing responses associated with decreased membrane resistance. Hyperpolarizations induced by muscarine increased their amplitudes at membrane potential between -70 and $-50 \mathrm{mV}$. Baclofen- and NE-induced hyperpolarizations were less sensitive to voltage. The agonist-induced hyperpolarizations decrease in amplitudes and reversed at a membrane potential between -90 and $-100 \mathrm{mV}$. $\mathrm{Ba}^{2+}(1 \mathrm{mM})$ blocked all agonistinduced hyperpolarizations in DLSN neurons. Tetraethylammonium (TEA, 3 $\mathrm{mM}$ ) blocked the muscarine-induced hyperpolarization but not the hyperpolarizations induced by the other agonists. Extracellular $\mathrm{Cs}^{+}$and glibenclamide did not block the agonist-induced hyperpolarizations. These results suggest that muscarine, 5-HT, adenosine, baclofen and $\mathrm{NE}$ cause the hyperpolarization by increasing the activity of $\mathrm{Ba}^{2+}$-sensitive $\mathrm{K}^{+}$channels, probably the GTP-binding protein (G-protein) activated inward rectifier $\mathrm{K}^{+}$ (GIRK) channels in DLSN neurons.
\end{abstract}

Key words dorsolateral septum, transmitter, modulation, inward rectifier $\mathrm{K}^{+}$channel, hyperpolarization

\section{Introduction}

It is known that in the mammalian central nervous system (CNS) some neurotransmitters modulate the efficacy of synaptic transmission mediated by other neurotransmitters by changing membrane excitability of postsynaptic neurons and/or transmitter release from presynaptic nerve terminals. At the postsynaptic membrane, neurotransmitter agonists cause either a hyperpolarization or a depolarization of the neuronal membrane by changing the permeability of ion channels termed ligand-gated channels (North, 1989). Previously, it has been reported that in the CNS receptors for several neurotransmitters share the same ligand-gated $\mathrm{K}^{+}$channels to hyperpolarize the neuronal membrane (Andrade et al. 1986). Several studies have reported that the ligand-gated $\mathrm{K}^{+}$

All correspondences to Prof. T. Akasu, Department of Physiology, Kurume University School of Medicine, 67 Asahi-machi, Kurume 830, Japan. Tel: +81-942-31-7543 Fax: +81-942-31-7728 
channel shows an inward rectifier property at hyperpolarizing potentials in central neurons (North et al. 1987; North, 1989). Recently, a family of cDNAs cloning subunits of the GTPbinding protein (G-protein) activated inward rectifier $\mathrm{K}^{+}$(GIRK) channels has been described (Dascal et al. 1993; Kubo et al. 1993). The dorsolateral septal nucleus (DLSN), that belongs to the mammalian limbic system, receives many inputs from other CNS nuclei including the hippocampus (Jakab and Leranth, 1995). It has been shown that muscarine, 5-hydroxytryptamine (5-HT), adenosine and baclofen cause hyperpolarizing responses by activating a $\mathrm{K}^{+}$ conductance in DLSN neurons. These agonists also activate a G-protein in DLSN neurons. However, the properties of the $\mathrm{K}^{+}$channels activated by these agonist receptors are not well understood. The present study shows that muscarine, 5-HT, adenosine, baclofen and norepinephrine (NE) cause hyperpolarizing responses associated with increase in $\mathrm{K}^{+}$conductance in DLSN neurons. We discuss the properties of $\mathrm{K}^{+}$channels linked with the muscarine, 5-HT, adenosine, baclofen and $\mathrm{NE}$ receptor in relation to currently identified GIRK channels.

\section{Materials and Methods}

Brain slices that contain the DLSN were made from rats in a manner described elsewhere (Stevens et al. 1984; Gallagher and Hasuo, 1989). Briefly, male Wistar rats were sacrificed by decapitation, and brain slices containing DLSN were cut in $500 \mu \mathrm{m}$ thickness with a brain slicer (Vibroslicer; Campden Co. Ltd.). A slice was transferred to a recording chamber (volume $3 \mathrm{ml}$ ) continuously superfused with oxygenated $\left(95 \% \mathrm{O}_{2} / 5 \%\right.$ $\mathrm{CO}_{2}$ ) Krebs solution of the following composition (mM): $\mathrm{NaCl}, 117.0 ; \mathrm{KCl}, 4.7$; $\mathrm{CaCl}_{2}, 2.5 ; \quad \mathrm{MgCl}_{2}, \quad 1.2 ; \quad \mathrm{NaH}_{2} \mathrm{PO}_{4}, 1.2 ;$ $\mathrm{NaHCO}_{3}, 25.0$ and D-glucose, 11.0. The $\mathrm{pH}$ of the superfusing solution was 7.4. The perfusion rate was maintained at 2.5 $\mathrm{ml} / \mathrm{min}$. Intracellular microelectrodes filled with $3 \mathrm{M}$ K-acetate had a tip resistance of 90-140 $\mathrm{M} \Omega$. The membrane voltage and current were amplified with an Axoclamp 2B (Axon Instruments) and monitored continuously with a penwriting recorder (RJG-4122, Nihon Kohden) and memory oscilloscope (VC10, Nihon Kohden). Voltage and current were also digitized and stored in a computer (Gateway 2000) with data acquisition system (P-clamp) for the later analysis. All agonists except glibenclamide were dissolved in the Krebs solution. Glibenclamide was dissolved in alcohol and added to the Krebs solution; the final concentration of alcohol (0.1\%) had no direct effect on DLSN neurons. Of the drugs used in the present study, muscarine, 5-HT, adenosine, norepinephrine (NE), baclofen and glibenclamide were purchased from Sigma Chemical Co. Tetraethylammonium chloride was obtained from Tokyo Kasei. All experiments were carried out at a temperature of $30-32{ }^{\circ} \mathrm{C}$.

\section{Results}

Neurons in the rat DLSN had resting membrane potential of $-64.0 \pm 7.1 \mathrm{mV}(\mathrm{n}=$ 54 ) and input resistance of $107 \pm 36 \mathrm{M} \Omega$ 


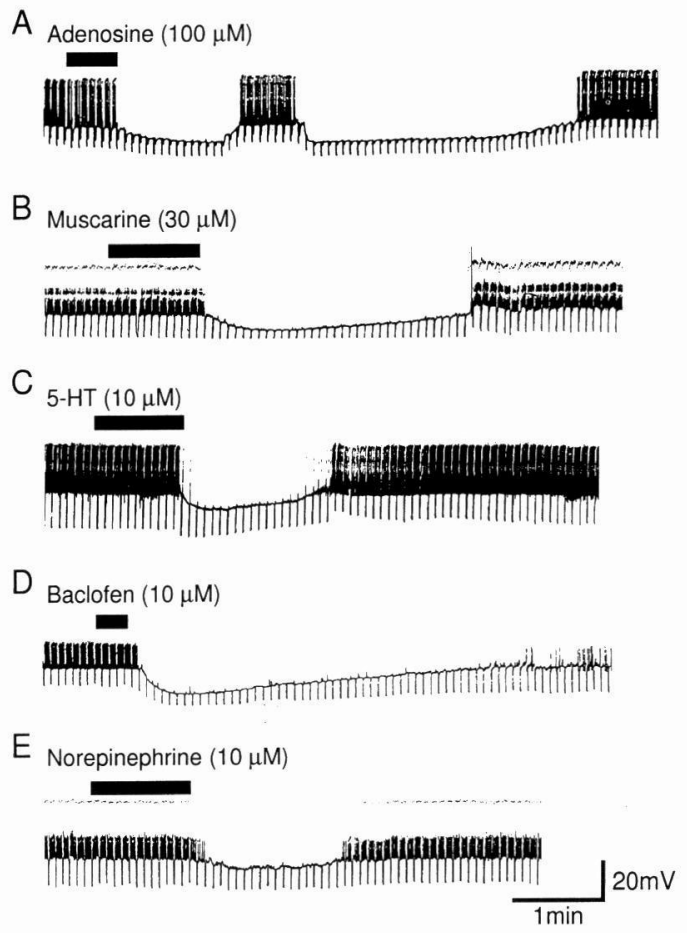

Fig. 1. Hyperpolarizations induced by adenosine $(100 \mu \mathrm{M})$, muscarine $(30 \mu \mathrm{M}), 5$ HT $(10 \mu \mathrm{M})$, baclofen $(10 \mu \mathrm{M})$ and NE $(10$ $\mu \mathrm{M})$ in DLSN neurons. Each record is from a different neuron. Downward deflections are electrotonic potentials produced by rectangular current pulses with duration of $200 \mathrm{~ms}$. Upward deflections indicate spontaneous firing of action potentials. Horizontal bars indicate the period of application of agonists. In record (A), a depolarizing current was applied for approximately 1 minute to nullify the adenosine-induced hyperpolarization.

$(n=54)$ at the resting membrane potential. Figure 1 shows examples of the hyperpolarizing effect of adenosine (100 $\mu \mathrm{M})$, muscarine $(30 \mu \mathrm{M}), 5$-HT $(10 \mu \mathrm{M})$, baclofen $(10 \mu \mathrm{M})$ and NE $(10 \mu \mathrm{M})$ on DLSN neurons. When adenosine $(100 \mu \mathrm{M})$ was added to the superfusing solution, the resting membrane potential increased in 8 out of 10 neurons. The two remaining neurons showed no obvious changes in the resting membrane potential. The adenosine-induced hyperpolarization was associated with a decrease in input resistance, which persisted when the hyperpolarization was nullified by applying anodal (depolarizing) current (Fig. 1A). Muscarine $(30 \mu \mathrm{M})$ also caused a hyperpolarizing response in 4 out of 7 neurons (Fig. 1B). A depolarizing response was produced by muscarine $(30 \mu \mathrm{M})$ in 2 neurons, while in the remaining neuron, muscarine $(30 \mu \mathrm{M})$ caused no response. Application of 5-HT $(10 \mu \mathrm{M})$ to the Krebs solution caused a hyperpolarizing response in almost all DLSN neurons tested $(n=8)$ (Fig. 1C). The hyperpolarizing responses induced by muscarine and 5-HT were associated with decrease in input resistance. Baclofen $(10 \mu \mathrm{M})$, a $\mathrm{GABA}_{\mathrm{B}}$ receptor agonist, also caused a hyperpolarizing response associated with decreased input resistance in DLSN neurons ( $n=8)$ (Fig. 1D). No depolarizing response was produced by application of baclofen to DLSN neurons. The baclofeninduced hyperpolarization lasted for 10 min after termination of the application of baclofen. NE, at a concentration of 10 $\mu \mathrm{M}$, caused a hyperpolarization in 10 DLSN neurons (an example in Fig. 1E), a depolarizing response in 2 neurons and no response in 2 neurons. The NEinduced hyperpolarization was associated with a decrease in input resistance.

Figure 2 shows voltage-current relationships (V-I curves) constructed by application of rectangular current pulse with duration of $200 \mathrm{msec}$. In the absence of agonist (control), the V-I curve shows decreased membrane resistance at hyper- 

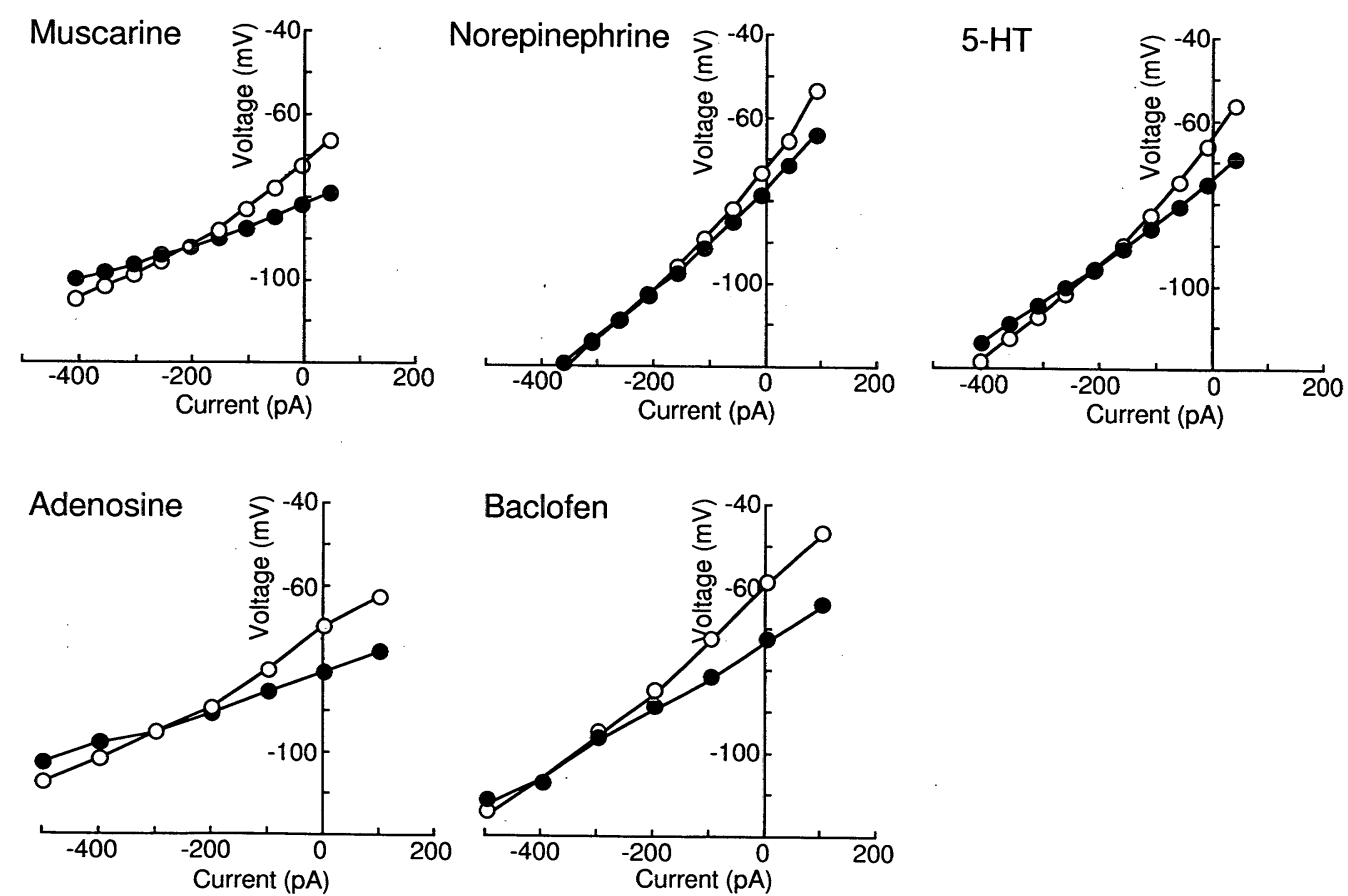

Fig. 2. Relationship between membrane potential and current (V-I curve) obtained before $(\bigcirc)$ and during $(O)$ the application of agonists. The resting membrane potentials were between -60 and $-72 \mathrm{mV}$. V-I curve was obtained by injecting anodal or cathodal current pulses with duration of $200 \mathrm{~ms}$.

TABLE 1.

Peak amplitude and reversal potentials of the hyperpolarizations produced by muscarine, 5-HT, adenosine, NE and baclofen in DLSN neurons

\begin{tabular}{|c|c|c|}
\hline & Amplitude & Reversal potential \\
\hline Muscarine $(30 \mu \mathrm{M})$ & $8.8 \pm 2.2 \mathrm{mV}(\mathrm{n}=7)$ & $-96.8 \pm 7.9 \mathrm{mV}(\mathrm{n}=7)$ \\
\hline$(10 \mu \mathrm{M})$ & $13.9 \pm 3.0 \mathrm{mV}(\mathrm{n}=7)$ & $-96.0 \pm 6.5 \mathrm{mV}(\mathrm{n}=7)$ \\
\hline Adenosine $(100 \mu \mathrm{M})$ & $8.1 \pm 3.0 \mathrm{mV}(\mathrm{n}=8)$ & $-93.0 \pm 5.1 \mathrm{mV}(\mathrm{n}=7)$ \\
\hline$(10 \mu \mathrm{M})$ & $8.3 \pm 1.5 \mathrm{mV}(\mathrm{n}=4)$ & $-95.0 \pm 4.1 \mathrm{mV}(\mathrm{n}=4)$ \\
\hline Baclofen $(10 \mu \mathrm{M})$ & $14.3 \pm 3.5 \mathrm{mV}(\mathrm{n}=6)$ & $-89.0 \pm 3.9 \mathrm{mV}(\mathrm{n}=4)$ \\
\hline
\end{tabular}

Resting membrane potential $-60 \mathrm{mV}$. The number of experiments is shown in parentheses. The reversal potential was obtained from the intersection of V-I curves. Data represents mean \pm SE. 
TABLE 2.

Effect of $\mathrm{K}^{+}$channel blockers on the hyperpolarizations induced by muscarine, 5-HT, NE and baclofen in DLSN neurons

\begin{tabular}{cccccc}
\hline & & $\begin{array}{c}\text { Muscarine } \\
(30 \mu \mathrm{M})\end{array}$ & $\begin{array}{c}5-\mathrm{HT} \\
(10 \mu \mathrm{M})\end{array}$ & $\begin{array}{c}\mathrm{NE} \\
(10 \mu \mathrm{M})\end{array}$ & $\begin{array}{c}\text { Baclofen } \\
(10 \mu \mathrm{M})\end{array}$ \\
\hline $\mathrm{TEA}$ & $(3 \mathrm{mM})$ & + & - & - & - \\
$\mathrm{Ba}^{2+}$ & $(1 \mathrm{mM})$ & + & + & + & + \\
{$\left[\mathrm{Cs}^{+}\right]_{0}$} & $(1 \mathrm{mM})$ & - & - & - & - \\
$\mathrm{GC}$ & $(100 \mu \mathrm{M})$ & - & - & - & - \\
\hline
\end{tabular}

Data were obtained from 4-6 cells for each blocker. Drugs were applied to the superfusing solution for $5-10 \mathrm{~min}$. A response depression by more than $50 \%$ is represented as + . No depression of agonist-induced hyperpolarization is indicated by -. GC: glibenclamide.
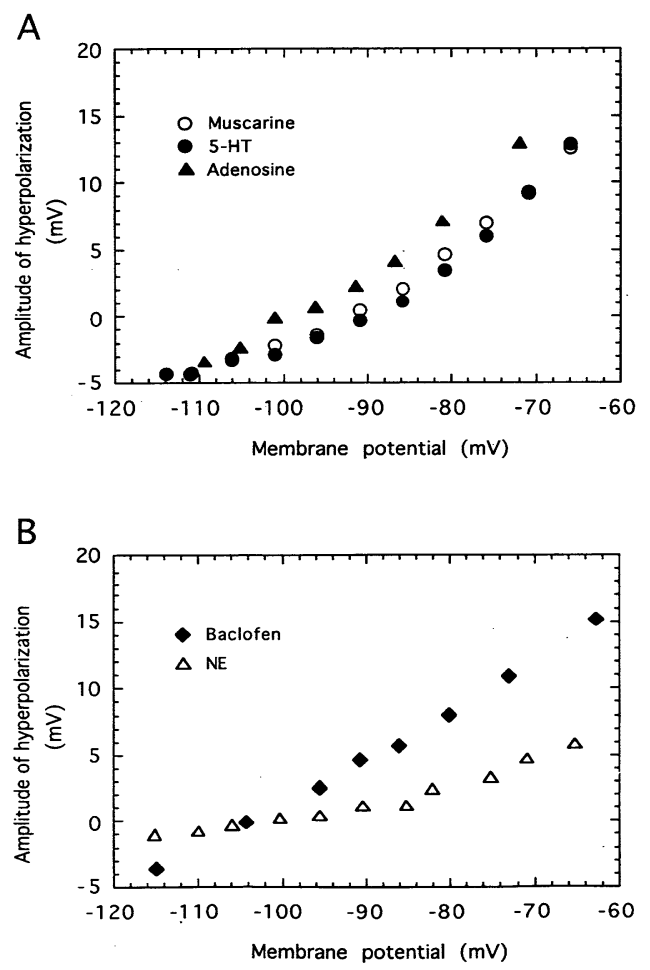

Fig. 3. Relationship between membrane potential and the amplitude of the response induced by muscarine, 5-HT and adenosine (A) and baclofen and NE (B). The amplitudes of agonist-induced responses were obtained by subtraction of control V-I curves from those taken in the presence of agonists. polarized membrane potentials (inward rectification). During the muscarineinduced hyperpolarization, the V-I curve intersected the control curve at $-92 \mathrm{mV}$ (Fig. 2). The hyperpolarizations produced by NE, 5-HT, adenosine and baclofen also reversed their polarities at a potential between -90 and $-100 \mathrm{mV}$. The reversal potentials of these agonistinduced hyperpolarizations are summarized in Table 1. These results suggest that in DLSN neurons all these hyperpolarizations are produced by activation of a $\mathrm{K}^{+}$conductance. We next examined the voltage-dependency of the agonistinduced hyperpolarizations. Figure 3 shows the relationship between the amplitude of the agonist-induced responses and the membrane potential in DLSN neurons; the membrane potential was estimated from the control V-I curve. The amplitude of the responses induced by muscarine, 5 -HT and adenosine showed an almost linear relation to membrane potential at potentials between -70 and $-110 \mathrm{mV}$, while the amplitude of the hyperpolarization was somewhat increased at membrane potentials less negative than $-90 \mathrm{mV}$ (Fig. 3A). The hyperpolarizations 
A Control

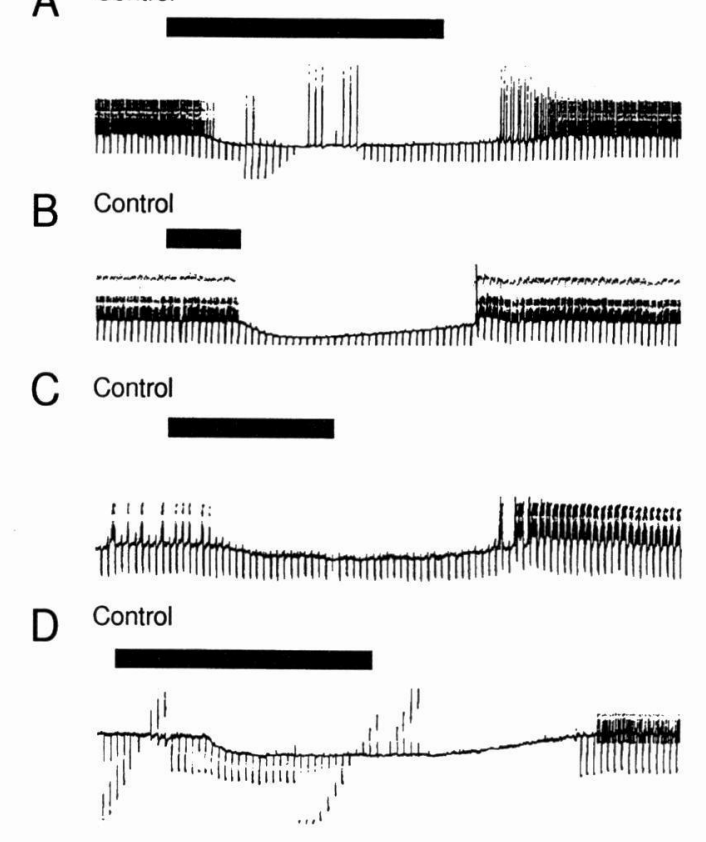

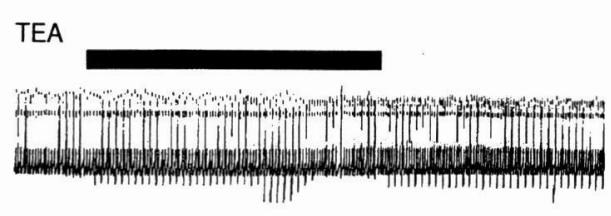

$\mathrm{CsCl}$

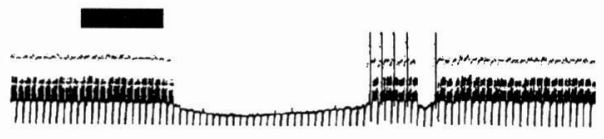

$\mathrm{BaCl}_{2}$

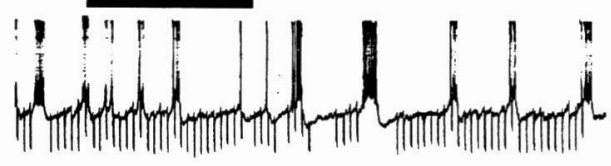

Glibenclamide

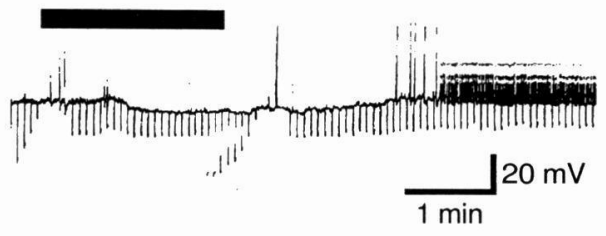

Fig. 4. Effects of TEA (A), $\mathrm{CsCl}$ (B), $\mathrm{BaCl}_{2}$ (C) and glibenclamide (D) on the muscarine-induced hyperpolarization. Records (A)-(D) were taken from different neurons. Horizontal bars indicate the period of bath-application of muscarine. Downward and upward deflections indicate the electrotonic potentials and spontaneous action potentials, respectively. The concentration of TEA, $\mathrm{CsCl}, \mathrm{BaCl}_{2}$ and glibenclamide were $3 \mathrm{mM}, 1 \mathrm{mM}, 1 \mathrm{mM}$ and $100 \mu \mathrm{M}$, respectively.

induced by baclofen and NE were also clearly seen at hyperpolarizing membrane potentials (Fig. 3B).

We next examined the effects of $\mathrm{K}^{+}$ channel blockers on the agonist-induced hyperpolarization. The muscarine-induced hyperpolarization was depressed by application of tetraethylammonium (TEA, $3 \mathrm{mM}$ ) to DLSN neurons (Fig. 4). $\mathrm{Ba}^{2+}(1 \mathrm{mM})$ also depressed the muscarine-induced hyperpolarization. However, extracellular $\mathrm{Cs}^{+}(1 \mathrm{mM})$ and glibenclamide $(100 \mu \mathrm{M})$ did not block the muscarine-induced hyperpolarization
(Table 2). TEA (3 mM) and $\mathrm{Ba}^{2+}(1 \mathrm{mM})$ depolarized the resting membrane potential and increased the firing rate of spontaneous action potentials. $\mathrm{Ba}^{2+}(1$ $\mathrm{mM}$ ) also blocked the hyperpolarizations induced by 5-HT, NE and baclofen (Fig. 5). However, TEA (3 mM), extracellular $\mathrm{Cs}^{+}(1 \mathrm{mM})$ and glibenclamide $(100 \mu \mathrm{M})$ did not block the hyperpolarizations induced by 5-HT, NE and baclofen. These results are summarized in Table 2. Intracellular $\mathrm{Cs}^{+}$has been known as a nonselective blocker for $\mathrm{K}^{+}$channels (Hille, 1992). In the present study, $\mathrm{Cs}^{+}$ 
A Control

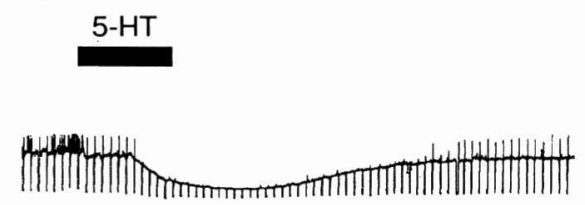

B Control

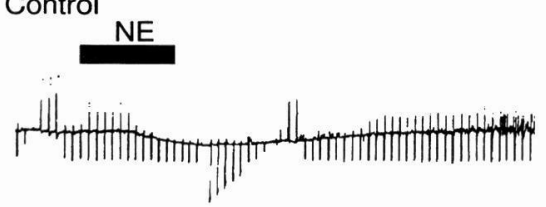

C Control

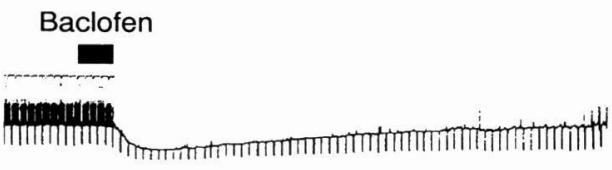

$\mathrm{BaCl}_{2}$
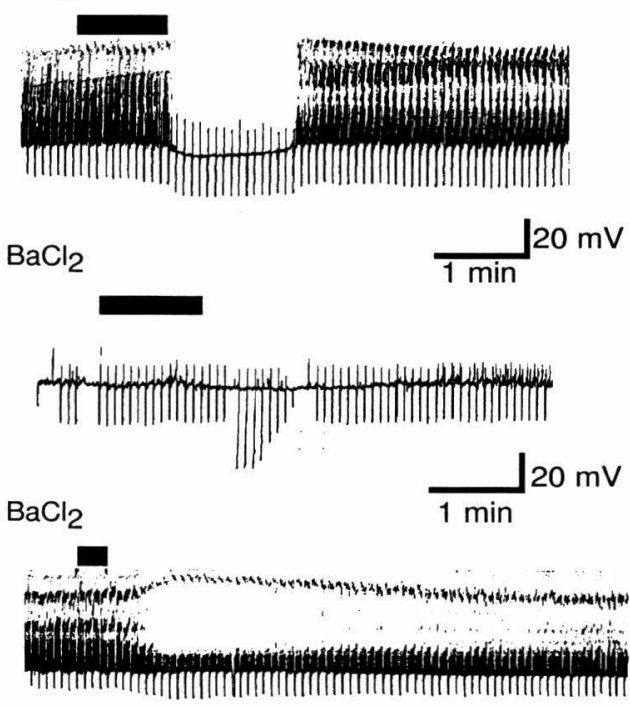

$20 \mathrm{mV}$

Fig. 5. Effects of $\mathrm{BaCl}_{2}(1 \mathrm{mM})$ on the hyperpolarizations induced by 5 -HT $(10 \mu \mathrm{M})$, $\mathrm{NE}(10 \mu \mathrm{M})$ and baclofen $(10 \mu \mathrm{M})$. Records obtained from different cells. Horizontal bars indicate the period of bath-application of 5-HT (A), NE (B) and baclofen (C). Downward and upward deflections indicate electrotonic potentials and spontaneous action potentials, respectively.

was injected into DLSN neurons through an intracellular microelectrode filled with $3 \mathrm{M} \mathrm{CsCl}$. Injection of $\mathrm{Cs}^{+}$into DLSN neurons for 10-20 min caused depolarization associated with spontaneous firing of action potentials characterized by a prolonged plateau on the falling phase. The amplitude of the 5-HTinduced hyperpolarization was decreased in $\mathrm{Cs}^{+}$-treated DLSN neurons. However, the 5-HT hyperpolarization reappeared, when the neuron was depolarized by application of anodal current. Intracellular $\mathrm{Cs}^{+}$shifted the reversal potential of the 5-HT-induced hyperpolarization to a more depolarizing potential.

\section{Discussion}

The present study shows that transmitter agonists such as muscarine, 5-HT, adenosine, NE and baclofen cause hyperpolarizing responses associated with increased $\mathrm{K}^{+}$conductance in DLSN neurons. Electrical properties of agonistinduced hyperpolarizations were analyzed by utilizing V-I curves. The hyperpolarizations induced by muscarine, 5-HT and adenosine could be recorded at hyperpolarized potentials, although they showed no clear inward rectification. $\mathrm{Ba}^{2+}$ is known to block the inward rectifier $\mathrm{K}^{+}$current in various central 
neurons (North, 1989; Hille, 1992). In our study, $\mathrm{Ba}^{2+}(1 \mathrm{mM})$ blocked the hyperpolarization induced by muscarine, 5-HT and adenosine. However extracellular $\mathrm{Cs}^{+}$did not block the agonist-induced hyperpolarization. Glibenclamide has been reported to be a selective blocker for the ATP-sensitive $\mathrm{K}^{+}$channel (Sturgess et al. 1985; Schmid-Antomarchi et al. 1987). In DLSN neurons, glibenclamide blocks the hyperpolarization induced by glucosedepletion (Akasu et al. 1996). However, glibenclamide $(100 \mu \mathrm{M})$ was not effective as a blocker for the agonist-induced hyperpolarization in DLSN neurons. The present study also shows that TEA (3 $\mathrm{mM}$ ) blocks the muscarine-induced hyperpolarization but not the hyperpolarizations induced by 5 -HT or the other agonists. The $\mathrm{K}^{+}$channels that link with muscarinic receptors might be different in nature from those linked with other agonists. It has been shown that TEA selectively blocks a voltage-dependent $\mathrm{K}^{+}$channel, the delayed rectifier $\mathrm{K}^{+}$ channel (Hille, 1992). However, the delayed rectifier $\mathrm{K}^{+}$current does not seem to be involved in the muscarinic hyperpolarization, because muscarine also caused a hyperpolarizing response in DLSN neurons that had been treated with intracellular $\mathrm{Cs}^{+}$. These pharmacological properties imply that the hyperpolarizations induced by muscarine, 5$\mathrm{HT}$, adenosine, baclofen and $\mathrm{NE}$ are produced by activation of a GIRK channels (North et al. 1987; North, 1989; Dascal et al. 1993; Kubo et al. 1993). However, the present study showed no obvious inward rectifier properties in these agonist-induced hyperpolarizations. Further studies using the voltage-clamp technique are needed to identify the $\mathrm{K}^{+}$ channel coupled to muscarinic receptors, $\mathrm{GABA}_{\mathrm{B}}$ receptors as well as receptors for 5-HT, adenosine and NE.

Acknowledgments: Most of this study was supported by The Ishibashi Research Fund and a Grant-in-Aid for Scientific Research from the Ministry of Education, Science and Culture of Japan.

\section{References}

Akasu T, Tsurusaki M, and Shoji S. Depletion of glucose causes presynaptic inhibition of neuronal transmission in the rat dorsolateral septal nucleus. Synapse 1996; 24:125-134.

Andrade R, Malenka RC, and Nicoll RA. A G protein couples serotonin and $\mathrm{GABA}_{\mathrm{B}}$ receptors to the same channels in hippocampus. Science 1986; 234:1261-1265.

Dascal N, Schreibmayer W, Lim NF, Wang W, Chavkin $\mathrm{C}$ et al. Atrial $\mathrm{G}$ protein-activated $\mathrm{K}^{+}$ channel: Expression cloning and molecular properties. Proc Natl Acad Sci USA 1993; 90:10235-10239.

Gallagher JP, and Hasuo H. Excitatory amino acid-receptor-mediated EPSPs in rat dorsolateral septal nucleus neurones in vitro. $\mathrm{J}$ Physiol (Lond) 1989; 418:353-365.

Hille B. Ionic Channels of Excitable Membranes, 2nd edn. Sinauer, Sunderland, 1992.

Jakab RL, and Leranth C. Septum. In: The Rat Nervous System, 2nd edn. ed. Paxinos G, Academic Press, San Diego, pp 405-442, 1995.

Kubo Y, Reuveny E, Slesinger PA, Jan NY, and Jan LY. Primary structure and functional expression of a rat G-protein-coupled muscarinic potassium channel. Nature 1993; 364:802-806.

North RA. Drug receptors and the inhibition of nerve cells. Br J Pharmacol 1989; 98:13-28.

North RA, Williams JT, Surprenant A, and Christie MJ. $\mu$ and $\delta$ receptors belong to a family of receptors that are coupled to 
potassium channels. Proc Natl Acad Sci USA 1987; 84:5487-5491.

Schmid-Antomarchi H, De Weille J, Fosset M, and Lazdunski $M$. The receptor for antidiabetic sulfonylureas controls the activity of the ATP-modulated $\mathrm{K}^{+}$channel in insulinsecreting cells. J Biol Chem 1987; 262:1584015844.
Stevens DR, Gallagher JP, and ShinnickGallagher P. Intracellular recordings from rat dorsolateral septal neurons, in vitro. Brain Res 1984; 305:353-356.

Sturgess NC, Ashford MLJ, Cook DL, and Hales $\mathrm{CN}$. The sulphonylurea receptor may be an ATP-sensitive potassium channel. Lancet 1985; 8453:474-475. 